\title{
WRITTEN COMMUNICATION IN ENTREPRENEURSHIP COURSE IN MALAYSIAN VOCATIONAL COLLEGES: A QUALITATIVE INQUIRY
}

\author{
Hamidah Mohamad ${ }^{1}$ \\ Kuliyyah of Education, International Islamic University Malaysia. \\ (Email: hamidah_md@hotmail.com) \\ Faizah Idrus ${ }^{2}$ \\ Kuliyyah of Education, International Islamic University Malaysia. \\ (Email: ifaizah@iium.edu.my)
}

Received date: $14-07-2019$

Revised date: $15-10-2019$

Accepted date: 16-10-2019

Published date: 15-12-2019

To cite this document: Mohamad, H., \& Idrus, F. (2019). Written Communication in Entrepreneurship Course in Malaysia Vocational Colleges: A Qualitative Inquiry. International Journal of Education, Psychology and Counseling, 4 (33), 22-40.

DOI: $10.35631 /$ IJEPC.433003

\begin{abstract}
Entrepreneurship curriculum has been implemented in recent years in Malaysian vocational colleges as a platform to expose school leavers to entrepreneurship skills and provide them the basic know-how needed to engage in an entrepreneurial career. Among this knowledge is written communication which involves the skill of preparing the necessary documents and correspondence in a start-up business. However, research findings indicate that very little is known about Malaysian vocational college graduates' competency in this area after completing the entrepreneurship course. Moreover, existing studies show significant weaknesses or a lack of competency in communication skills, including writing among our graduates. This study aims to explore the implementation of written communication components taught in the entrepreneurship course in Malaysian vocational colleges by examining its curriculum content and teaching approaches utilised in the course. The study applied the qualitative approach using semi-structured interviews and document analysis to gather the data. 15 instructors from 10 vocational colleges located throughout Peninsular Malaysia participated in the interviews. Meanwhile, the document analysis included a course description, modules, teaching plan, lecture notes, coursework, and assignments as well as assessment materials of the course. The results revealed that the business plan model is applied to form the fundamental structure of the written communication component in the entrepreneurship course. However, several key challenges were found in its implementation, including the ambiguity and inconsistency in the key focal point within the written communication knowledge area. Additionally, short and inconsistent course delivery periods were also identified as barriers to effective implementation of the target knowledge as well as the course in general.
\end{abstract}


Keywords: Entreprenuership Education, Written Communication, Curriculum Design and Implementation, Technical and Vocational Education

\section{Introduction}

Research in the field of entrepreneurship education (EE) has witnessed a dramatic growth in the past two decades, covering areas of curriculum framework, teaching and learning models as well as their role in creating entrepreneurs (Fayolle, 2016; Nabi, Liñán, Fayolle, Krueger, \& Walmsley, 2016). Some of the most discussed issues within these domains include the effectiveness of $\mathrm{EE}$ in promoting the intention and inclination among students to consider entrepreneurship as a career choice as well as concerns in providing students with the right preparation, skills and knowledge in embarking into an entrepreneurial career (Ghina, 2014; Sirelkhatim \& Gangi, 2015; Premand, Brodmann, Almeida, Grun, \& Barouni, 2016). Within these discussions, the roles of government, institutions, educators and the attributes of learners have been considered, among others in the investigations of EE (Lee, Hebaishi, \& Hope, 2015; Hasan, Khan, \& Nabi, 2017).

In the Asian regions, the avid interest in EE has been further propelled by the increasing concern in the issue of graduate employability and the trend of promoting soft-skill, life-long learning skills and employability skills, especially within the tertiary education domain (Zamberi Ahmad, 2013; Kasim, Zulkharnain, Hashim, Ibrahim, \& Yusof, 2014). As a result, EE programs and courses have been developed and offered more actively than ever in various ways i.e. via academic programs, TVET and professional development programs. The rapid growth and intensity in the development of EE in the region have also raised the interest among scholars and stakeholders to view the issues of quality and functions of EE at a macro level (national or institutional domain) and micro level (personal domain), especially in addressing the needs of the societies in these countries.

Technical and vocational education has been recognized and used as a platform to provide the young generation with this opportunity. The main aim of TVET has been primarily to groom and fulfil the need for highly skilled workforce to support the growth of the industrial sector. At the same time, it also seeks to expose students to entrepreneurship skills with the intention to create an interest and provide them the basic know-how to establish a career in entrepreneurial line. This is evident in one of the objectives of the establishment of vocational college in Malaysia, which is to produce at least 10 percent vocational education graduates that are capable in becoming competitive entrepreneurs (BPTV, 2018).

Considering these goals, the curriculum of the programs and courses related to entrepreneurship competency offered in TVET institutions, namely the vocational college needs to address certain key skill areas, communication being one of them. This is necessary to prepare graduates with the practical know-how and competencies other than the academic-based knowledge relevant to real life applications. In identifying entrepreneurial competencies, Xiang Li (2019) identified communications as a key competency which include person-to-person or individualto-group-based interactions, e.g. building a context of cooperation and trust, using contacts and connections, persuasive ability, among others. Meanwhile, in a guideline on soft-skills domain in higher learning institutions of Malaysia by the Ministry of Higher Education (2015), communication skills cover among others the ability to be fluent and able to communicate effectively in both Bahasa Malaysia and English language. Graduates should be able to convey their thoughts with clarity and confidence both in written and oral forms and are expected to be 
active listeners while providing the necessary response. They should also be able to give presentations confidently and employ technology in their communications.

However, the lack of standardisation in the curriculum, namely for EE related courses and programs creates gaps in the training content, teaching, and learning of communication skills, namely written communication skills because TVET provision in Malaysia is undertaken by different ministries, agencies and organizations, both public and private, with a multiplicity of certification, standards and curricula (Ismail \& Hassan, 2015). Moreover, although studies have shown that graduates from the Malaysian education system have shown significant weaknesses or a lack of competency in this area (Ahmad, 2014), the implementation of teaching and learning of written communication are unknown within the domain of vocational college education in Malaysia as most studies done in the country are focused on school students, university graduates, businessmen/entrepreneurs and academics (Wan Nur Azlina Ibrahim, Ab. Rahim Bakar, Soaib Asimiran, Shamsiah Mohamed \& Noor Syamilah Zakaria, 2015).

In light of these, this study aims to to explore the implementation of written communication skills covered in the entrepreneurship education syllabus in vocational college curriculum in Malaysia. Specifically, the investigation seeks to identify the extent of the written communication content covered in the curriculum in relation to the entrepreneurship course's goals as well as the methods used to deliver the target skills or knowledge. In determining these, the study endeavours to identify the effectiveness, strengths and weaknesses of the EE curriculum in relation to the teaching and learning of written communication. In addition to this, the research also seeks to fill the gap in the particular field of study, hence contributing to the existing body of literature. The study also hopes to yield meaningful insights that can be used in improving the current policies and practices related to the teaching and learning of written communication in fulfilling entrepreneurship education curriculum goals in the context of Malaysian vocational college.

\section{Literature Review}

Entrepreneurship education was first pioneered in the early $21^{\text {st }}$ century at Kobe University, Japan by Shigeru Fijii (Lackéus, 2016). However, it was offered formally as courses and programs at American higher learning institutions, mainly via their business schools. This has eventually led to entrepreneurship education being recognised as a legitimate academic field (Franke \& Luthje, 2004). According to (Binks \& Mahon, 2006), entrepreneurship education is the pedagogical process involved in the encouragement of entrepreneurial activities, behaviours and mindsets. In other words, entrepreneurship education is aimed at inspiring and grooming current and future entrepreneurs as well as promoting entrepreneurial culture among younger generation to make them consider it as a part of their career choice (Deakins et. al, 2005). In order to achieve this, Robinson and Haynes emphasised that 'the design of entrepreneurship education curriculum need to be creative, innovative, imaginative and most importantly [tie] academic learning to the real world' (1991).

\section{Key Themes in EE Research}

\section{Implementation of EE Curriculum}

Investigation and discussions on EE curriculum are one of the most prevalent areas of research in EE across the globe Iglesias-Sánchez, Jambrino-Maldonado, Velasco, \& Kokash, 2016). Within this theme, the most prevalent argument revolves around the importance as well as effectiveness of the curriculum in producing entrepreneurs and in providing students with the necessary skills, particularly related to employability to prepare them for their future career. 
The studies examined EE curriculum's significance mostly from students' perception, instructors' feedback as well as analysis of the materials and approaches used in the EE programs offered in the HLIs (Ahmad \& Buchanan, 2016; Ahmad, Ismail, \& Buchanan, 2014; Chang, Liu, \& Chiang, 2014; Din, Anuar, \& Usman, 2016; Hasan et al., 2017; Othman \& Nasrudin, 2016; Rahim et al., 2015).

Although findings suggest that the stakeholders acknowledge the importance of EE in higher learning in providing students with entrepreneurial knowledge and skills, the approaches used were found to be too traditional and academic-oriented as opposed to the hands-on skills and experiences the students should gain from the curriculum (Ahmad et al., 2014; binti Othman \& Hanisah Othman, 2017; Olugbola, 2017; Othman \& Nasrudin, 2016; Smith et al., 2015). Although numerous EE curriculum frameworks proposed by $\mathrm{EE}$ scholars and experts emphasise the application of participatory and experiential approaches to match graduates' formal training in EE with the real-world entrepreneurial skills and know-how, the findings suggest a gap exists between EE curriculum applied in the HLIs and entrepreneurship practices in the regions (Ahmad et al., 2014; Chang et al., 2014; Chen et al., 2015; Ghina, 2014; Rahim et al., 2015; Yusoff, Zainol, \& Ibrahim, 2014).

In addressing this, a number of studies explored the implementation of a more industry-oriented curriculum i.e. by engaging industry in the learning process and offering work-based learning opportunities to students in addressing employability issues faced in the community (Bustamam et al., 2015; Goldstein, Ick, Ratang, Hutajulu, \& Blesia, 2016; Morselli et al., 2014; Olugbola, 2017; Ooi \& Nasiru, 2015; Rahim et al., 2015; Shih \& Huang, 2017; Kirkwood et al., 2014). Having said that, the findings are predominantly limited to specific population since the studies were focused on local settings; hence, not all the findings are generalizable to the context outside of these settings.

\section{Entrepreneurial Intention and Inclination}

Entrepreneurial intention and inclination are another popular area of theme in the research of EE. The main focus of investigations lies on the factors that influence students' intention or inclination towards entrepreneurial career. The findings reveal that among the most cited influences of entrepreneurial intention and inclination are the teaching and learning approaches applied in the EE curriculum, both in terms of the theoretical knowledge, as well as the handson experiences that students gain from the EE programs, as well as the students' background, namely demographic profile, attitude and motivation and past experience in entrepreneurial activities (Bustamam et al., 2015; Chuah \& Ting, 2015; Ibrahim, Bakar, Asimiran, Mohamed, \& Zakaria, 2015; Kirkwood et al., 2014; Kusumastuti, 2015; Mohamad, Lim, Yusof, \& Soon, 2015; Mohamed, Rezai, Mustapha \& Selvaraju, 2015; Olugbola, 2017).

\section{Practices of EE Pedagogy}

The third emerging theme found to be common in the research of EE is the pedagogical approaches as well as their effectiveness and impact on the success of EE programs. The emphasis of the inquiries is placed on the teaching models which stress the inculcation of handson or practical skills, exposure to real-life entrepreneurial environment and engagement of industry-based learning. Among the most common approaches applied or examined in these studies include: 1) experiential learning (Ahmad et al., 2014; Chang et al., 2014; Goldstein et al., 2016; Huq \& Gilbert, 2013; Ibrahim et al., 2015; Ismail, 2013; Kirkwood et al., 2014; Kusumastuti, 2015; Lee et al., 2015; Mohamad et al., 2015; Morselli et al., 2014; Olugbola, 2017; Sondari, 2014; Yusoff et al., 2014), 2) consulting-based EE (Bustamam et al., 2015; Mustapha \& Selvaraju, 2015; Othman \& Nasrudin, 2016), 3) competency-based learning 
(Affero \& Hassan, 2013; Hasan et al., 2017; Ismail, 2013; Kusumastuti, 2015), 4) work-based approach (Huq \& Gilbert, 2013; Keat et al., 2011; Nizam Zainuddin \& Rozaini Mohd Rejab, 2010), and 5) blended approach (Kirkwood et al., 2014; Kusumastuti, 2015) . Findings revealed that pedagogy practices that allow students to gain as much as practical skills and provide them the exposure to actual entrepreneurial practices are crucial to the effectiveness and success of EE programs.

\section{Issues in EE}

Recent research in EE also covered investigations and discussions on challenges and setbacks, mostly in the implementation and achievement of EE goals. It is important to note that although a large portion of the studies selected in this review did highlight or bring up the issues faced in their respective EE domains, only a handful of research reported them as major findings. The synthesis of these findings formed two main sub-themes, namely the current scenario of EE programs and initiatives, and the challenges with implementation and practices.

In the first part, the key issue highlighted is the lack of cohesion and synergy in the philosophy and structure of EE at HLIs, especially in the context of national education framework (Ahmad \& Buchanan, 2016; Rahim et al., 2015; Yusoff et al., 2014). This was caused by the lack of clear guidelines and policies related to EE, which lead to inconsistent understandings of the objectives and practices in different HLIs i.e. TEVT as well as their stakeholders. Some of the major problems highlighted include ineffective syllabus, inappropriate teaching approaches, unqualified instructors and lack of standard implementation guidelines (Ahmad \& Buchanan, 2016; Ahmad et al., 2014; Ismail, 2013; Yusoff et al., 2014; Othman \& Nasrudin, 2016). The disparities between EE goals and practices call for a revision and improvement of the current EE policies and guidelines to empower EE, especially in meeting the needs of the nation and the stakeholder.

\section{Communication Skills as a Component of Entrepreneurship Education}

Within the Malaysian education framework, MOHE instituted compulsory entrepreneurship syllabus (Robuan, Jaén, \& Liñán, 2017) for all public and private institutions of higher education in Malaysia to introduce soft-skill elements and set up entrepreneurial culture module (Ismail, et al., 2010). Hence, it launched EE programs in all the higher learning institutions in order to boost the entrepreneur development among the graduating students (Gafar et. al, 2014). In the discussion of the significance of soft skills at the Malaysian higher learning institutions, Azmi, Hashim, and Yusoff (2018) highlighted entrepreneurship skills and communication skills as part of the key competencies included in the curriculum of programs offered at this level. Other than these two skills, critical thinking and problem-solving skills, teamwork, lifelong learning and information management skills as well as professional moral and leadership skills were also listed as the soft skills elements covered in the framework Azmi, Hashim, and Yusoff (2018). It is interesting to note that entrepreneurship skills are identified as a separate domain from communication skills, as both encompass large spheres of sub-skills and competencies. However, within the entrepreneurship skills domain, communication is viewed as a variable of entrepreneurship competency ( $\mathrm{Li}, 2009$; Weber \& Spartz, 2014). Consistent to the its objectives, the present study applies this approach in its investigation of the implementation of written communication in EE curriculum.

The framework of soft skills implementation in Malaysian institutes of higher learning as outlined by the Ministry of Higher Education Malaysia (2015) revealed that soft skills, including entrepreneurship skills are taught in three methods: 1) in the form of focused nonacademic programs, 2) embedded into academic programs as stand-alone subjects, and 3) 
through campus lifestyle. In addition, two additional methods that are not included in the model but nevertheless used within the education system which are the 'soft' finishing school and practical industrial training Azmi, Hashim, and Yusoff (2018). The study concluded by remarking that at present, there are no clear guidelines on assessing the level of soft skills as institutions adopted individual approaches in implementing the skills. This is especially true for TVET institutions in the country, including vocational college.

In addition, the investigation on the teaching and learning of written communication is guided by Problem-based Learning and Experiential Learning theories. The theories argue that students are encouraged to actively work with material and turn to the teacher for advice, mentorship, and answers to specific problems instead of being passive recipients of lectures (Klofsten; 2000; Spence, 2001; Hanke et al., 2005). Teaching and learning include collaborative activities, goaldriven tasks, intellectual discovery, activities that heighten thinking and activities that provide practice in learning skills. In the context of EE, students can develop the skills and required knowledge effectively through the application of the entrepreneurial curriculum in situations that resemble the real business world (Norasmah et al., 2017).

Based on the study's objective and theory discussed above, a conceptual framework (Fig. 2) is established to support the current research's paradigm. The framework identifies three elements: 1) the entrepreneurship education curriculum applied in the vocational college domain that forms the foundation to the course content, 2) the theoretical framework that underpins the teaching approaches, and 3) the written communication skills taught and applied as the target competency in learning. The elements are studied to explore the links between content, teaching methods and learning of the skills.

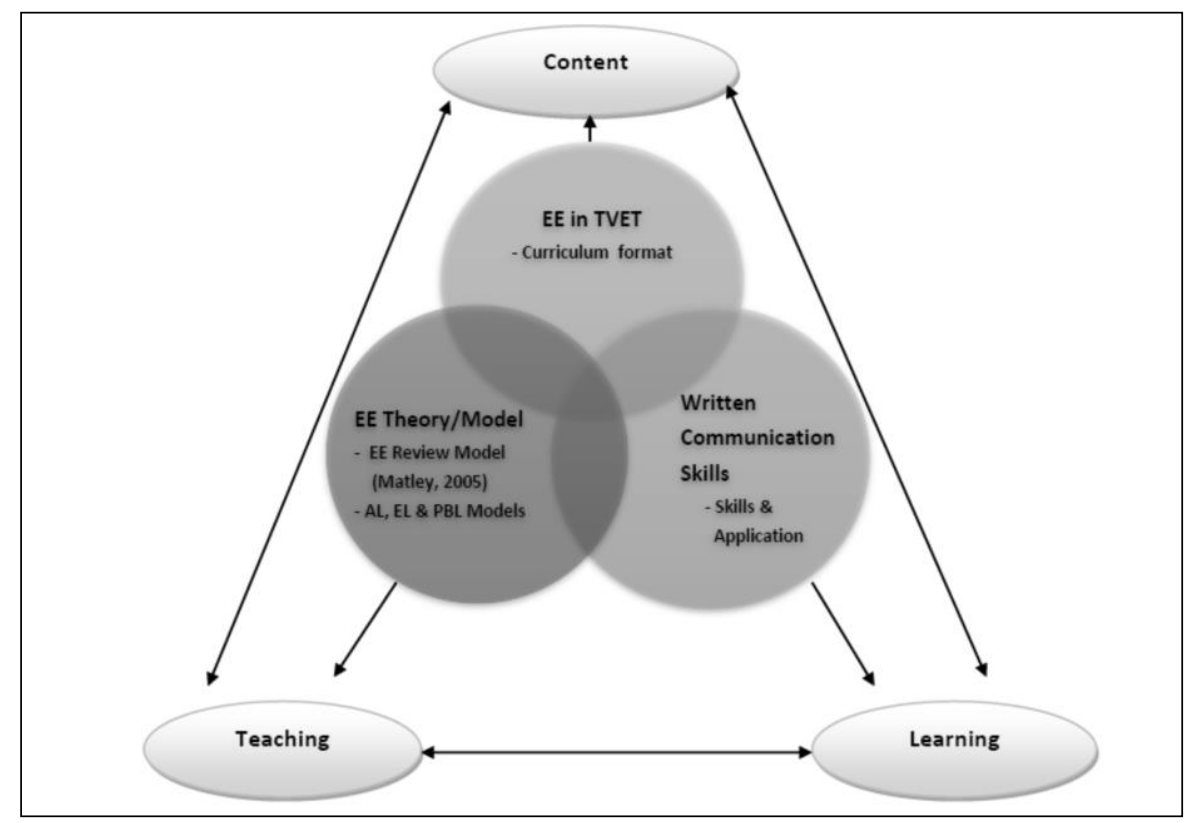

Figure 1: Conceptual Framework of the Study

\section{Methodology}

\section{Research Design and Instrument}

In order to achieve this research's objectives, two qualitative approaches were employed, namely directed document analysis and semi-structured interview. The directed content 
analysis approach involved an investigation on the curriculum of EE related course in selected government-run vocational colleges. This was carried out by looking into available documents such as course description, modules, coursework and other relevant materials to identify the presence and application of written communication skills component as well as the depth of its coverage. The findings from the investigation were analysed to identify the emerging themes associated with components of written communications skills, guided by the relevant research findings to establish the initial coding.

The second approach, the semi-structured interview is intended to extract personal opinions of entrepreneurship course's instructors concerning the implementation of written communication skills component through the EE related programs/courses' syllabus in the TVET institution. They were asked about practices and their views on these (Cassell, 2015). The instrument, namely interview questions and protocol (refer Appendix) were tested in a pilot study involving an instructor who taught the entrepreneurship course in a vocational college in Selangor, after which minor improvements were made to refine it for better clarity. The interviews were recorded (with the permission of the respondents) and subsequently transcribed into written format, thus bringing the researcher close to the data (Molina-Azorin, 2016).

\section{Population, Sampling and Data Analysis}

\section{Population}

A total of 16 vocational colleges from 4 zones: North, South, East, West of Peninsula Malaysia (4 from each zone) were identified as the population area of the sampling. Out of these, 10 colleges agreed to participate in the research. The states from which the vocational colleges' respondents comprising entrepreneurship instructors as well as various course materials were obtained included Kedah, Penang and Perak (North), Negeri Sembilan and Johor (South), Pahang (East) and Selangor (West). The population was selected as a way to obtain data from vocational colleges located at different parts of the country to see if differences exist in the practices within these zones.

For semi-structured interview, purposive sampling was employed (Cassell, 2015) and target respondents included instructors, namely those who conduct and coordinate the specific EE related course. The findings from the investigation then were analysed for the emerging themes associated with the teaching and learning of written communications. The data from the interviews were analyzed using a thematic coding (Braun, Clarke \& Weate, 2016). Meanwhile, for the directed content analysis, the available documents and materials were studied based on established curriculum of entrepreneurship education.

\section{Sampling and Data Analysis for Directed Document Analysis}

For the directed content analysis, various types of documents and materials were studied based on established criteria for entrepreneurship education curriculum. The criteria were identified based on the prescribed content within the framework of EE by established education governance bodies in Malaysia, particularly related to vocational education at post-secondary level as well as existing EE models/framework found or proposed in existing body of research on EE. In addition, the documents and materials used in teaching entrepreneurship course(s) in the selected vocational colleges were also be examined as they may vary from each other. A checklist based on the determined criteria was used to identify the needed data and establish variable categorization and establish the analysis guidelines. 


\section{Sampling and Data Analysis for Semi-Structured Interview}

For the semi-structured interview, purposive sampling was employed, and target respondents included teaching staff, namely those who coordinate and entrepreneurship course in the vocational colleges in Malaysia. A total of 10 interview sessions were conducted in the respective zones of the country involving 15 instructors who participated either in individual or group interviews form. Data saturation was achieved after 7 interviews. The interviews were then transcribed, coded and analyzed manually to derive the emerging themes associated with the implementation of written communication in the entrepreneurship course offered in the vocational colleges.

\section{Credibility and Trustworthiness}

The current study attempted to achieve elements of credibility and trustworthiness in the data analysis in at least two ways, namely by triangulation and member-checking. To achieve triangulation of data, the research engages two different types of data (Bryman, 2017) The findings from the interview with the entrepreneurship course instructor is corroborated using document analysis of the entrepreneurship course taught at the institution to assist in reviewing the overall findings of the research (Creswell \& Poth, 2017). Meanwhile, member checking was done by sharing the transcription and initial findings with the participants as well as the researcher's supervisor, who is a qualitative research expert to ensure the accuracy of the interview protocol, transcription and coding of the interviews as well as document analysis. Other than that, a pilot study and discussion with entrepreneurship course instructor from one of the vocational colleges was also carried out to ensure that the instruments are clear and truthful. The feedback received from these parties were used to refine the findings and analysis.

\section{Findings and Discussion}

This section is divided into two main parts. The first part reports the key findings derived from the interview and document analysis, whereas the second part presents the discussion of the findings in relation to the research objective of the study.

\section{Results of Semi-Structured Interviews and Document Analysis}

\section{Semi-Structured Interviews}

The data of this study were derived from two sources: i) semi-structured interview and ii) directed document analysis. Data from the interview were based on the 10 semi-structured interviews involving 15 participants who are instructors and coordinators of 10 government run vocational colleges located all over the country. The interviews were transcribed and coded. Most of the interviews were carried out in Bahasa Melayu, with a couple of them done in English language or in mixed code between both the language, based on the preference of the participants. Hence, where Bahasa Melayu was used, the interviews were translated into English language. Both the transcription and translated versions were put through member checking with the participant to verify and ensure their accuracy. Then, analysis was carried out using the data to identify the emerging and recurring categories and based on these, the key themes were identified.

\section{Document Analysis}

Meanwhile, results for document analysis presented in this paper were obtained from the course outline of the course A10800: Keusahawanan, which is a course offered under the purview of Department of Technical and Vocational Education (BPTV), Ministry of Education Malaysia to provide a basic exposure to entrepreneurship for students of vocational college. The main goal of the course is to provide students with knowledge in the field of entrepreneurship as a 
preparation to enter the job market or to consider entrepreneurship as a career option. Meanwhile, the skills acquired in the course are aimed towards exposing students to the key concepts of entrepreneurship and the process of preparing a comprehensive business plan. The current syllabus outline that is being implemented was last revised in May 2014 by BPTV. The course comprises 28 contact hours consisting of 10 chapters of guided learning, theory, practical, independent learning, preparation and revision, assignments, presentation and final examination. The course learning outcomes (CLO) are shown in Table 2.

Table 1: CLO for A10800 - Entrepreneurship Course at Vocational College (translated) Source: BPTV (2018)

\begin{tabular}{|c|c|}
\hline CLO 2 & $\begin{array}{l}\text { Understand, appreciate and practice the characteristics of } \\
\text { entrepreneurship in life }\end{array}$ \\
\hline CLO 3 & Use computer software to set up business plans \\
\hline CLO 4 & $\begin{array}{l}\text { Prepare a business plan and evaluate the feasibility of a business } \\
\text { opportunity }\end{array}$ \\
\hline CLO 5 & $\begin{array}{l}\text { Produce a Business Plan that is acceptable and appropriate to the } \\
\text { financial institution's requirement for a loan }\end{array}$ \\
\hline CLO 6 & $\begin{array}{l}\text { Appreciate and practice entrepreneurial ethics in business as well as } \\
\text { daily life }\end{array}$ \\
\hline CLO 7 & Strengthen the interest in entrepreneurial care \\
\hline
\end{tabular}

Other than that, rubrics/marking schemes and sample of BPs given in the module and students' work are also considered in this analysis.

Based on the analysis of the data derived from both sources, two major themes on written communication elements in the entrepreneurship course offered at vocational colleges are elaborated in this paper, as listed below:

- Features of Written Communication Component

- Approaches in Teaching and Learning

The breakdown of the categories and themes are shown in Table 2.

Table 2: Summary of Categories, Themes and Sub-Themes

\begin{tabular}{|c|c|c|}
\hline Categories & Themes & Sub-themes \\
\hline $\begin{array}{ll}- & \text { Types of EE courses } \\
\text { - } & \text { Status of the course } \\
\text { - } & \text { Writing component coverage } \\
\text { - } & \text { Written documents/skills } \\
\text { - } & \text { Course duration } \\
& \text { Theory - Application } \\
\text { distribution } \\
\text { - } & \begin{array}{l}\text { Business plan - content and } \\
\text { coursework }\end{array} \\
\end{array}$ & $\begin{array}{l}\text { Feature of } \\
\text { Written } \\
\text { Communication } \\
\text { Component }\end{array}$ & $\begin{array}{l}\text { 1. Types of Courses } \\
\text { 2. Written } \\
\text { Communication } \\
\text { Content } \\
\text { 3. The Business Plan }\end{array}$ \\
\hline $\begin{array}{l}\text { Emphasis on hands-on } \\
\text { learning }\end{array}$ & $\begin{array}{l}\text { Teaching and } \\
\text { Learning } \\
\text { Approaches }\end{array}$ & $\begin{array}{l}\text { 1. Teaching Methods } \\
\text { 2. Learning } \\
\text { Objectives }\end{array}$ \\
\hline
\end{tabular}




\begin{tabular}{|ll|}
\hline - & Strategies and activities done \\
& in the course \\
- & Instructor's roles \\
- & Materials and activities \\
- & Assessment strategies \\
\hline
\end{tabular}

\section{Theme 1: Feature of Written Communication Component in the Entrepreneurship Course}

\section{The Course and Its Component}

Based on the information obtained from the participant, it was found that the government run vocational colleges run only one EE related course, namely 'Keusahawanan' or 'Entrepreneurship' under the course code A10800. The course is a compulsory subject that all students must enrol and pass before completing their study at the college, and it is classified under the General Studies category. Furthermore, this courses' enrolment policy is applied in all the TVET institutions under the category, namely the vocational colleges in Malaysia. The course is a short-semester subject, offered between 8- to 14-week period at the end of year for Form 4 students who are also in their Year 1 of Diploma Vokasional Malaysia (DVM). There are inconsistencies in the scheduling of the course among the different colleges studied, whereby the course class/instruction period can vary from a whole day class over few days within a week or in smaller sessions i.e. 2-4 hours per week in 3-4 sessions.

The respondents tend to suggest that written communication component, which is also associated with the theoretical aspect of the course covers the major part of the syllabus' coursework component and learning output, although the emphasis on the actual written communication skill is not considered as imperative in performing well in the course. Instead, students are taught and drilled on following a given format of preparing written communication tasks, namely the Business Plan (BP) being the primary coursework of the course. Students are taught to develop the BP in stages from the beginning of the semester in groups and they are required to submit the completed $\mathrm{BP}$ at the end of the semester, right after they present it to the class.

"...the emphasis is on how to develop a business plan ...the whole course is about developing business plan..." (BEA14)

Although the course objective highlights the emphasis on hands-on approach to teaching and learning, the findings from the interviews revealed that in terms of the implementation, the practices applied are more traditional, namely theory and lecture-based approach. One instructor even mentioned that:

"...They [the students] need more like spoon-feeding... the expectation of the students more to the lecturers only... so everything we have to give them and they have to make sure that they follow the thing, everything... the procedures." (SPB75)

The reasons given for this include the fact that the students are still deemed by the instructors to be school students at secondary level and they are mostly described as weak academically. Hence, the students need the 'spoon-feeding' as way to cope with the course. 
The respondents also emphasised that the Business Plan is the primary type of written communication or document included in the syllabus of Entrepreneurship course, whereas other types of written communications such as business registration documentation, business loan application, marketing plan, accounts statements and financial management reports are taught as part of the BP:

\section{"...We teach the Business Plan, we also teach other documents related to business registration and loan application...” (PDA54)}

Business Plan as the key component of the course syllabus covers extensive content and skill sets, including written communication. The components are spread out into 10 chapters and are taught throughout the semester, from which students are given the coursework and tasks based on the specific skill areas or chapters covered, including writing the Business Plan. The stages of the Business Plan development applied in the course are summarised in Figure 3.

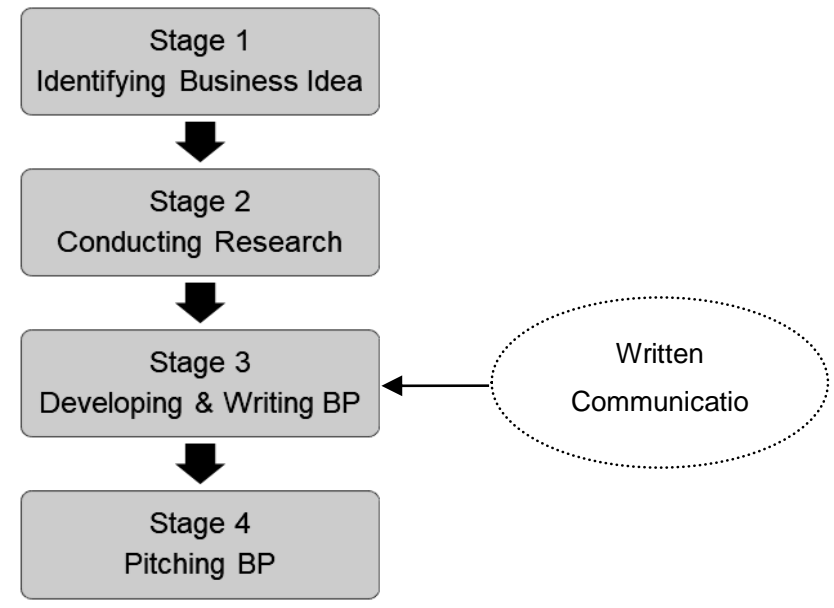

Figure 2: Stages in Business Plan Development in A10800 Course

The written communication component comes into play most prominently at Stage 3, where students are required to compose their business ideas in writing before presenting them in the following step, the pitching stage via the presentation of the BP. The emphasis on the composing aspect of the BP is more focused on the descriptive aspect of the Business Plan i.e. describing information ('menjelaskan maklumat'), preparing plan ('menyediakan rancangan') whilst the emphasis in the language aspect is vague or unavailable, as observed in both the course description (A10800) and the marking scheme for the Business Plan final report (elaborated further in Section 4.1.2).

\section{Theme 2: Approaches in Teaching and Learning}

In terms of teaching, several methods were employed by the participant based on both the prescribed content in the syllabus as well as in relation to the additional content and skills added on to increase the students' knowledge. One of the key methods is to conduct activity-based and group-based tasks together with lecture-based teaching aimed to make the learning more interesting, engaging and easier for the students as many students are not inclined into academic learning style and many came into the program with poor academic results in SPM (SPB124; BEN87; SHA173). The contents are also delivered in stages and in smaller portions throughout 
the semester. Among the main hands-on task that are assigned to the students is to approach and engage with local entrepreneurs as part of research and data collection prior to developing their own BP. The exercise allows the students to have an exposure of real-life entrepreneurial practices.

Other than that, parallel to the hands-on and activity-based approach, the respondents practice student engagement outside the class hours:

“...we do not limit ourselves to the classroom.” (BWA80)

"In truth, [communication] outside the classroom is much more helpful." (BWA82)

This is done with two-pronged goals. The first is to allow students the opportunity to explore and include materials outside the classroom instruction (lectures and modules) and their own knowledge and experience gained from research and engagements with entrepreneurs into their BP. The second is to cope the tight scheduling of the short semester which takes place at the end of the academic year and which overlaps with the school holiday. Students are required to carry out independent work (research and writing for the BP) in-between the instruction period (first 3 to 5 weeks) and presentation week (end of the semester) to optimise the break period and gaps between the classes so that they can complete the BP and the relevant tasks in time.

However, to provide extra help to the students over the independent work period, the instructors claimed that they would make themselves available for consultations during the off-class hours, either via face-to-face mode or communication mediums (phone, text-messaging or social media platforms) (SPB, SIA, JBA). Besides being a monitoring strategy of students' work-inprogress, it was found to be a helpful approach for many students who have low-self-esteem and are shy or afraid to ask questions in the classroom:

"...students of vocational college have awfully low self-esteem. They are afraid to ask questions in the class, they fear their friends will laugh at them." (SIA82)

In terms of assessment, the respondents apply the evaluation system provided in the course syllabus and they contain among others, tests and quizzes as well as group activities and projects. The quizzes and tests predominantly evaluate the theoretical knowledge while the projects and activities assess the entrepreneurial and literacy skills learned in the course. In terms of the written communication component, the emphasis of the assessment tends to lie on the format and content of the BP. The greater part of the mark allocation is given to the students' compliance to the structure of the BP and providing the right information for each section as shown in the sample BPs and instructions given in the modules and lectures:

"...in the module, the format is given. There are also samples of complete Business Plan with the module... we tell them, teach them to follow the format and also the sample." (SHA113)

Meanwhile, the mark allocation for language skills i.e. grammar, sentence structure, vocabulary etc. is either non-existent or vague, and instructors are given the freedom to provide a subjective and open assessment and mark allocation for this aspect of the BP. The assessment allocation for language aspect covers between $1 \%$ to $3 \%$ of the total mark allocation for BP among several 
colleges, while in others, it was either not clearly specified or it is simplified under the 'Accuracy' component in the marking rubric (refer Table 2 - No. 2(c)). In this regard, several instructors even claimed that language skills-set is not a fundamental area in the assessment of the BP, mostly because students tend to 'recycle' and 'reuse' contents from the samples or BPs done by previous students or those available online (KJA, SPB, BWA, PDA). They would only change the relevant contents to 'personalise' and suit their own ideas of the start-up business they propose to run in the BP, as clearly highlighted in these feedbacks from the instructors:

"...usually the students just change the details in the BP... they take other $B P$ maybe from samples. Some even take from internet... change here and change there based on their own business idea... you know, like copypaste." (BWA165)

“...I just accept the BP... its fine even if they recycle from others. As long as they make the necessary changes... because they still need to think about what business they want to do, what is their logo, they have to do all that on their own..." (PDA97)

Besides, these instructors view written communication as a non-priority competency area for vocational students and TVET in general as the area is associated with the academic skill-set which the students tend be poor at or disinclined in, as opposed to the technical core knowledge that offered in the main programs in vocational institution.

“...you know, these vocational kids not into writing... They are technical field... the writing part in the BM or English subjects they emphasise la..." (SPB67)

“...for the Entrepreneurship module, we don't consider it [language] so much, I mean we don't need... not required to give, allocate marks for language... but I give la... for good language, I mean grammar, spelling... extra 2 marks..." (JBA106)

\section{Discussion}

Written communication is recognised as an important element of entrepreneurship competency as it is recognised as a contributing factor in leading to the success of a business (Honig \& Karlsson, 2004b; Spartz \& Weber, 2015). Entrepreneurs needs the know-how and skills in developing the necessary written documents as part of competency associated with 'technical communication', 'professional communication' or 'entrepreneurship communication' ( $\mathrm{Li}$, 2019; Spartz \& Weber, 2015; 2014) within in the broader context of entrepreneurship skills. This competency is specifically linked to the development of key documents linked to new ventures or start-ups, namely the Business Plan. Correspondingly, the entrepreneurship course in the government-run vocational college applies this widely held curricula format. This is in line with the previous research's findings whereby entrepreneurship curricula format which applies the Business Plan model has been dubbed as a popular curricula model for entrepreneurship education (Parimala, 2013).

The outline of the entrepreneurship course studied as well as the instructors' feedbacks reveal that the curriculum applied is parallel to most part of Honig's model (2004) of the Conventional Business Plan Curricula Format, which begins with the instruction on developing entrepreneurial business plan, followed by the entrepreneur completing the business plan, but 
the difference is noted in the last stage of the curricula model, which is the creation of a new business venture. The students' required output in the entrepreneurship course matches this framework up to the point of the formulation of the Business Plan. However, the course does not include any exercise on conducting any actual business activity as proposed in the last stage of Honig's model and to Norasmah's (2017) notion of real-life entrepreneurship curriculum. That being said, as far as the development of Business Plan is concerned, the implementation of the curriculum is hands-on, in line with course's learning outcome as well as PBL and EL theories which highlight learners' active participation in working with and developing the materials i.e. BP through collaborative activities with the teacher as the guide (Klofsten; 2000; Spence, 2001; Hanke et al., 2005).

In addition, the present study found several challenges with regards to the implementation of written communication within the teaching and learning of BP, namely the students' lack of interest, required skills and apprehension towards the course in general and written communication in specific. This phenomenon is driven by the orientation of vocational education which places emphasis on the core technical and industrial programs whilst the entrepreneurship course is offered as a supplementary 17 course to fulfil the soft-skills component (modul insaniah) of TVET education (BPTV, 2018) - evident in the period of the academic year and the short duration the course is offered. Moreover, students' low academic achievement level which are connotative to the entrance to vocational institutions in Malaysia is seen as a barrier to the learning of knowledge and skills involving written communication. These forms the juxtaposition that drives the instructors' ambiguous approach in their assessment the students' BP, especially with regards to the emphasis on format, leniency to 'recycling' and lack of emphasis on language accuracy. In addition, the short instruction period of 5-8 weeks adds to the difficulty that the instructors face in completing the comprehensive 10- chapter module to students who are already facing the challenges mentioned earlier. These findings are unique in the research within the overlapping contexts of EE in TVET and communication.

That being said, findings from the course instructor revealed that the exposure to the course did help in instilling an interest towards entrepreneurial career as there were students who actually expressed the intention to set up their own business and some even have become exceptionally successful entrepreneurs, especially those who came from business-owning families. The instructors' willingness to go the extra mile i.e. spending time to help and engage with students via consultations outside the given contact hours may have contributed to this, as highlighted in Bae, Qian, Miao and Fiet's (2014) study. This finding also supports the 'entrepreneurialdirected' approach which argues for the promotion of the close engagement between teachers and students in the learning process to stimulate entrepreneurial interest among the learners (Kirkley, 2017).

\section{Conclusion}

This research is aimed to investigate the implementation of written communication in entrepreneurship course taught at vocational college in Malaysia and examine the approach used with regards to the teaching and learning of written communication within the course in preparing graduates with entrepreneurship skills. The study employed the qualitative method in line with the study's objectives, namely the semi-structured interview and directed document analysis. The findings showed that the Business Plan is the primary curriculum model applied here and the teaching and learning methods are hands-on and practical in within and limited to BP development knowledge and skills. However, there is a persistent notion in both the outline of the entrepreneurship course as well as the instructor's feedback that the demarcation between 
the written communication and other skills i.e. numeracy and presentation (oral) skills within the curriculum as well as the implementation of the course is ambiguous due to broad structure of the syllabus which assess BP in terms of its format and content by including all of these skills but little on the specific language skills associated with written communication competency. A further investigation by examining students' written output and also by considering students' feedback can offer more insight on the significance written communication within EE curriculum

The findings of the present study also corroborate the conceptual framework of this study on the influence of the curriculum format of vocational college's entrepreneurship course in the determining the content, the framework of the entrepreneurship education models cited as well as the approaches of the written communication skills covered in relation to the students' learning needs. The findings of this study will yield meaningful insights that can be used in improving the current practices related to the teaching and learning of written communication with regards to fulfilling entrepreneurship education curriculum goals in Malaysian vocational college.

\section{References}

Affero, I., \& Hassan, R. (2013). Issues and Challenges of Technical and Vocational Education \& Training in Malaysia for Knowledge Worker Driven. National Conference on Engineering Technology 2014, 2013(2015), 1-11. https://doi.org/10.13140/2.1.4555.2961

Ahmad, S. Z., \& Buchanan, R. F. (2016). Entrepreneurship education in Malaysian universities, (November 2015). https://doi.org/10.1080/13583883.2015.1106577

Ahmad, S. Z., Ismail, M. Z., \& Buchanan, R. F. (2014). Examining the entrepreneurship curriculum in Malaysian polytechnics. International Journal of Management Education, (July 2014). https://doi.org/10.1016/j.ijme.2014.06.004

Azmi, I. A. G., Hashim, R. C., \& Yusoff, Y. M. (2018). The Employability Skills of Malaysian University Students. International Journal of Modern Trends in Social Sciences, 1(3), $1-14$.

Bae, T. J., Qian, S., Miao, C., \& Fiet, J. O. (2014). The Relationship Between Entrepreneurship Education and Entrepreneurial Intentions: A Meta-Analytic Review. Entrepreneurship: Theory and Practice, 38(2), 217-254. https://doi.org/10.1111/etap.12095

Binks, M., Starkey, K. and Mahon, C. L. (2006). Entrepreneurship education and the business school. Technology Analysis \& Strategic Management, 18(1), 1-18.

binti Othman, N., \& Hanisah Othman, S. (2017). The Perceptions of Public University Students of Entrepreneurship Education in Malaysia. Retrieved from http://docsdrive.com/pdfs/medwelljournals/ibm/2017/865-873.pdf

BPTV. (2018). https://www.moe.gov.my/korporat/bahagian-dan-unit/bahagian-pendidikanteknik-dan-vokasional

Braun, V., Clarke, V., \& Weate, P. (2016). Using thematic analysis in sport and exercise research. In Routledge handbook of qualitative research in sport and exercise (pp. 213227). Routledge. Bustamam, U. S. A., Mutalib, M. A., \& Yusof, S. N. M. (2015). Graduate Employability through Entrepreneurship: A Case Study at USIM. Procedia Social and Behavioral Sciences, 211(September), 1117-1121. https://doi.org/10.1016/j.sbspro.2015.11.149

Bryman, A. (2017). Quantitative and qualitative research: further reflections on their integration. In Mixing methods: Qualitative and quantitative research ( $\mathrm{pp}$. 57-78). Routledge. 
Cassell, C. (2015). Conducting research interviews for business and management students. Sage.

Chang, W. L., Liu, W. G. H., \& Chiang, S. M. (2014). A study of the relationship between entrepreneurship courses and opportunity identification: An empirical survey. Asia Pacific Management Review, 19(1), 1-24. https://doi.org/10.6126/APMR.2014.19.1.01

Chen, S. C., Hsiao, H. C., Chang, J. C., Chou, C. M., Chen, C. P., \& Shen, C. H. (2015). Can the entrepreneurship course improve the entrepreneurial intentions of students? International Entrepreneurship and Management Journal, 11(3), 557-569. https://doi.org/10.1007/s11365-013-0293-0

Chuah, F., \& Ting, H. (2015). Factors affecting entrepreneurial intention of Malaysian university students, (August 2016).

Creswell, J. W., \& Poth, C. N. (2017). Qualitative inquiry and research design: Choosing among five approaches. Sage publications.

Deakins, D., Glancey, K., Menter, I. \& Wyper, J. (2005). Enterprise education: The role of head teachers. International Entrepreneurship and Management Journal, 1(2), 241-263.

Din, B. H., Anuar, A. R., \& Usman, M. (2016). The Effectiveness of the Entrepreneurship Education Program in Upgrading Entrepreneurial Skills among Public University Students. Procedia - Social and Behavioral Sciences, 224(August 2015), 117-123. https://doi.org/10.1016/j.sbspro.2016.05.413

Fiet, J. O. (2015). ENTREPRENEURSHIP THEORY,

Franke, N., \& Luthje, C. (2004). Entrepreneurial intentions of business students-A benchmarking study. International Journal of Innovation and Technology Management, 1(03), 269- 288.

Ghina, A. (2014). Effectiveness of Entrepreneurship Education in Higher Education Institutions. Procedia - Social and Behavioral Sciences, 115, 332-345. https://doi.org/10.1016/j.sbspro.2014.02.440

Gilbert, D. H. (2012). From chalk and talk to walking the walk. Education + Training, 54(2/3), 152-166. https://doi.org/10.1108/00400911211210260

Goldstein, B. L., Ick, M., Ratang, W., Hutajulu, H., \& Blesia, J. U. (2016). Using the Action Research Process to Design Entrepreneurship Education at Cenderawasih University. Procedia - Social and Behavioral Sciences, 228(June), 462-469. https://doi.org/10.1016/j.sbspro.2016.07.071

Hasan, S. M., Khan, E. A., \& Nabi, M. N. U. (2017). Entrepreneurial education at university level and entrepreneurship development. Education + Training, 59(7/8), 888-906. https://doi.org/10.1108/ET-01-2016-0020

Honig, B. (2004). Entrepreneurship education: toward a model of contingency-based business planning. Academy of Management Learning \& Education, 3(3)(3), 258-273. https://doi.org/10.5465/AMLE.2004.14242112

Honig, B., \& Karlsson, T. (2004). Institutitonal forces and the written business plan. Journal of Management, 30(1), 29-48. https://doi.org/10.1016/j.jm.2002.11.002

Huq, A., \& Gilbert, D. H. (2013). Enhancing graduate employability through work-based learning in social entrepreneurship. Education + Training, 55(6), 550-572. https://doi.org/10.1108/ET-04-2012-0047

Ibrahim, W. N. A., Bakar, A. R., Asimiran, S., Mohamed, S., \& Zakaria, N. S. (2015). Impact of Entrepreneurship Education on the Entrepreneurial Intentions of Students in Technical and Vocational Education and Training Institutions (TVET) In Malaysia. International Education Studies, 8(12), 141. https://doi.org/10.5539/ies.v8n12p141

Iglesias-Sánchez, P. P., Jambrino-Maldonado, C., Velasco, A. P., \& Kokash, H. (2016). Impact of entrepreneurship programmes on university students. Education + Training, 58(2), 209-228. https://doi.org/10.1108/ET-01-2015-0004 
Kasim, R. S. R., Zulkharnain, A., Hashim, Z., Ibrahim, W. N. W., \& Yusof, S. E. (2014). Regenerating Youth Development through Entrepreneurship. Procedia - Social and Behavioral Sciences, 129, 322-327. https://doi.org/10.1016/j.sbspro.2014.03.683

Kirkley, W. W. (2017). Cultivating entrepreneurial behaviour: entrepreneurship education in secondary schools. Asia Pacific Journal of Innovation and Entrepreneurship, 11(1), $17-$ 37. https://doi.org/10.1108/APJIE-04-2017-018

Kirkwood, J., Dwyer, K., \& Gray, B. (2014). Students' reflections on the value of an entrepreneurship education. International Journal of Management Education, 12(3), 307-316. https://doi.org/10.1016/j.ijme.2014.07.005

Kusumastuti, D. (2015). Competency-based learning for effective entrepreneurship education at an Indonesian faculty of business and management. Journal of Institutional Research South East Asia, 13(2), 35-54.

Lackéus, M. (2016). A 'value' and 'economics' grounded analysis of six value creation based entrepreneurial education initiatives. In ECSB Entrepreneurship Education Conference.

Lee, K., Hebaishi, G., \& Hope, J. (2015). The role of senior management in developing and achieving a successful enterprise education programme? Education + Training, 57(7), 791-811. https://doi.org/10.1108/ET-11-2014-0139

Ministry of Higher Education (MoHE). (2015). Malaysia Education Blueprint 2015-2025 (Higher Education).

Mohamad, N., Lim, H.-E., Yusof, N., \& Soon, J.-J. (2015). Estimating the effect of entrepreneur education on graduates' intention to be entrepreneurs. Education + Training, 57(8/9), 874-890. https://doi.org/10.1108/ET-03-2014-0030

Molina-Azorin, J. F. (2016). Mixed methods research: An opportunity to improve our studies and our research skills.

Morselli, D., Costa, M., \& Margiotta, U. (2014). Entrepreneurship education based on the Change Laboratory. International Journal of Management Education, 12(3), 333-348. https://doi.org/10.1016/j.ijme.2014.07.003

Mustapha, M., \& Selvaraju, M. (2015). Personal attributes, family influences, entrepreneurship education and entrepreneurship inclination among university students. Kajian Malaysia, 33, 155-172. https://doi.org/10.16373/j.cnki.ahr.150049

Nabi, G., Liñán, F., Fayolle, A., Krueger, N., \& Walmsley, A. (2016). The impact of entrepreneurship education in higher education: A systematic review and research agenda. Academy of Management Learning \& Education, 16(2), amle.2015.0026. https://doi.org/10.5465/amle.2015.0026

Olugbola, S. A. (2017). Exploring entrepreneurial readiness of youth and startup success components: Entrepreneurship training as a moderator. Journal of Innovation \& Knowledge, 2(3), 155-171. https://doi.org/10.1016/j.jik.2016.12.004

Ooi, Y. K., \& Nasiru, A. (2015). Entrepreneurship education as a catalyst of business start-ups: A study on Malaysian community college students. Asian Social Science, 11(18), 350363. https://doi.org/10.5539/ass.v11n18p350

Othman, N., \& Nasrudin, N. (2016). Entrepreneurship education programs in Malaysian polytechnics. Education + Training, 58(7/8), 882-898. https://doi.org/10.1108/ET-112014-0136

Premand, P., Brodmann, S., Almeida, R., Grun, R., \& Barouni, M. (2016). Entrepreneurship Education and Entry into Self-Employment Among University Graduates. World Development, 77, 311-327. https://doi.org/10.1016/j.worlddev.2015.08.028

Rahim, H. L., Kadir, M. A. B. A., Abidin, Z. Z., Junid, J., Laila Mohd Kamaruddin, M., Lajin, N. F. M., ... Bakri, A. A. (2015). Entrepreneurship Education in Malaysia: a Critical Review. Journal of Technology Management and Business, 02(02), 1-11. 
Rengiah, P., \& Sentosa, I. (2016). The Effectiveness of Entrepreneurship Education in Developing Entrepreneurial Intentions Among Malaysian University Students : 5(02), 30-43

Robinson, P., \& Haynes, M. (1991). Entrepreneurship education in America's major universities. Entrepreneurship Theory and Practice, 15(3), 41-52.

Robuan, M. R. S., Jaén, I., \& Liñán, F. (2017). Promoting entrepreneurship in an unfavourable setting: a case study of a university programme in Malaysia. In The Emergence of Entrepreneurial Behaviour. Edward Elgar Publishing.

Shih, T., \& Huang, Y. Y. (2017). A case study on technology entrepreneurship education at a Taiwanese research university. Asia Pacific Management Review, 22(4), 202-211. https://doi.org/10.1016/j.apmrv.2017.07.009

Sirelkhatim, F., \& Gangi, Y. (2015). Entrepreneurship education: A systematic literature review of curricula contents and teaching methods. Cogent Business \& Management, 2(1), 111. https://doi.org/10.1080/23311975.2015.1052034

Smith, R. M., Tarndamrong, P., Sebora, T. C., \& Wolfe, C. A. (2015). Prepared to Launch? A Study of Thailand's New Entrepreneurs' Creation (NEC) Education Program. International Journal of Management Science \& Technology Information, 2014(16), $107-122$.

Sondari, M. C. (2014). Is Entrepreneurship Education Really Needed?: Examining the Antecedent of Entrepreneurial Career Intention. Procedia - Social and Behavioral Sciences, 115(Iicies 2013), 44-53. https://doi.org/10.1016/j.sbspro.2014.02.414

Spartz, J. M., \& Weber, R. P. (2015). Writing Entrepreneurs: A Survey of Attitudes, Habits, Skills, and Genres. Journal of Business and Technical Communication, 29(4), 428-455. https://doi.org/10.1177/1050651915588145

Weber, R., \& Spartz, J. M. (n.d.). Engaging entrepreneurship in technical communication using client and service-learning projects. Programmatic Perspectives, 6(1), 52-85.

Li, Xiang. (2019). Research on the Integration of Entrepreneurship Education and Professional Education in Universities. In 4th International Conference on Contemporary Education, Social Sciences and Humanities (ICCESSH 2019). Atlantis Press.

Yusoff, M. N. H. Bin, Zainol, F. A., \& Ibrahim, M. D. Bin. (2014). Entrepreneurship Education in Malaysia's Public Institutions of Higher Learning-A Review of the Current Practices. International Education Studies, 8(1), 17-28. https://doi.org/10.5539/ies.v8n1p17

Zamberi Ahmad, S. (2013). The need for inclusion of entrepreneurship education in Malaysia lower and higher learning institutions. Education + Training, 55(2), 191-203. https://doi.org/10.1108/00400911311304823 


\section{Appendix}

\section{Interview Questions}

Instrument: Semi-structured Interview Questions

Target Respondent: Entrepreneurship Course Instructor

\section{Key questions}

1. What are the types of written communication skills covered in the entrepreneurship

\section{Probe:} program/course taught at this institution?

i. What types of documents are included in the syllabus?

ii. Which of these documents is the most emphasised or important, i.e. with the largest mark allocation?

iii. What are the target skills that are aimed for the students through the learning of the written communication documents?

2. How is the written communication taught to students?

\section{Probe:}

i. How are the documents ordered throughout the course?

ii. How are the knowledge and skills delivered?

iii. What are the methods used to evaluate student's understanding of the knowledge/skill?

iv. What kinds of tasks are assigned for the written documents?

v. How are skills/knowledge assessed?

vi. What is the extent of theory vs. hands-on for the tasks assigned?

3. Based on your current and past experience in teaching the course, what is the students' Probe:

level of performance in terms of their grasp of the written communication skills taught?

i. What was the students' performance level before and after going through the course?

ii. How would you gauge the students 'ability in applying the written skills learned in real-life entrepreneurial or work-place situations?

iii.To what extent the skills level learned encourage student's interest in entrepreneurship career?

4. What are the issues or challenges instructors face in teaching the written communication skills/documents?

\section{Probe:}

i. What are the sources or areas where the issues/challenges are experienced?

ii. What are the strategies employed to overcome them (if any)?

iii. What improvements/recommendations that can be applied to enhance the current practices in the teaching and learning of the communication skills/documents? 